Acta Agroph., 2018, 25(1), 35-43

doi: $10.31545 /$ aagr0003

\title{
YIELD, SEED QUALITY AND NODULE FORMATION OF SOYBEAN UNDER APPLICATION OF EFFECTIVE MICROORGANISMS*
}

\author{
Dorota Gawęda, Małgorzata Haliniarz, Andrzej Woźniak, Elżbieta Harasim \\ Department of Herbology and Plant Cultivation Techniques, University of Life Sciences in Lublin, \\ Akademicka 13, 20-950 Lublin, Poland \\ e-mail: elzbieta.harasim@up.lublin.pl
}

Abstract. Soybean is a legume of high economic value, valued primarily for the high protein and oil content in its seed. Due to the advisability of seeking optimal solutions in the agronomy of this valuable legume, a study was undertaken to determine the effect of different fertilisation methods using preparations containing effective microorganisms (EM) on yield, content of some seed quality components and nodule formation of soybean. The experiment was set up in a randomised block design in three replicates, on plots with an area of $20 \mathrm{~m}^{2}$. The soybean cultivar 'Merlin' was grown. It was shown that application of mineral fertilisation supplemented with EM spraying was the most beneficial for soybean yield, followed by NPK fertilisation alone. All fertilisation treatments had a beneficial effect on protein content in soybean seed, compared to the control treatment. An opposite relationship was found in the case of the percentage oil content. The highest number and weight of nodules on soybean roots were noted in the treatment with EM spraying three times.

Keywords: Glycine max L., seed yield, EM, number and weight of nodules, seed chemical composition, structure of yield

\section{INTRODUCTION}

Due to the environmental disadvantages of intensive agricultural practices associated with the use of synthetic mineral fertilisers, there is a growing interest in using biofertilisers (Condor Golec et al. 2007, Elkoca et al. 2008) which include preparations that contain effective microorganisms in their composition (Mayer et al. 2010, Muthaura et al. 2010). Khaliq et al. (2006) showed that by applying EM mineral NPK fertilisation can be reduced to $50 \%$ of the recommended rate without a significant decrease in crop yield. The study by Javaid et al. (2008) demonstrates

* Research supported by the Ministry of Science and Higher Education of Poland as part of the statutory activities of the Department of Herbology and Plant Cultivation Techniques, University of Life Sciences in Lublin. 
that application of effective microorganisms can beneficially affect, among other things, root and stem growth as well as crop yield, which is largely dependent on the soil type.

Legumes are an important source of protein for humans, while their cultivation has a beneficial influence on soil fertility. Due to the above considerations, numerous studies on the agronomy and use of this group of crops are conducted in our country (Woźniak 2012, Woźniak, 2013, Łabuda and Buczkowska 2014). However, few of them relate to this valuable plant belonging to the Fabaceae family, as soybean undoubtedly is a valuable crop. It is now possible to grow this crop under the climatic and soil conditions of Poland and its cultivation brings expected production effects, among other things due to the breeding of cultivars adapted to our conditions as well as due to its high nutritional value and lower susceptibility to lodging compared to other legume crops. The existing research conducted in various parts of our country reveals that there is a high possibility of growing soybean, in particular in the south-eastern part of Poland (Gawęda et al. 2014; Harasim et al. 2016).

Soybean is a legume of high economic value, valued as a vegetable crop. Its seed contains $40 \%$ of protein, $20 \%$ of oil, and other valuable minerals, e.g. calcium, phosphorus and potassium. Soybeans are used for direct consumption and also for the production of processed foods, including dietary supplements and edible oil. The value of protein is determined by its amino acid composition; in the case of soybean, it is characterised by the content of valuable sulphur amino acids, that is, methionine and cysteine (Zeller 1999, Cederroth and Nef 2009). Due to the advisability of seeking optimal solutions in the agronomy of this valuable legume, that would facilitate, among other things, its cultivation that is fully effective productively and environmentally safe, a study was undertaken to determine the effect of different fertilisation treatments using EM preparations on yield, content of some seed quality components and nodule formation of soybean.

\section{MATERIALS AND METHODS}

Experimental design. A field study was carried out over the period of 20142015 at the Uhrusk Experimental Farm belonging to the University of Life Sciences in Lublin $\left(51^{\circ} 18^{\prime} 11^{\prime \prime} \mathrm{N}, 23^{\circ} 36^{\prime} 43^{\prime \prime} \mathrm{E}\right)$, on a mixed rendzina soil classified in the very

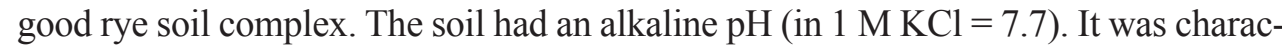
terised by very high availability of phosphorus in dry weight [DW] of soil (229.6 mg $\mathrm{P} \mathrm{kg}^{-1} \mathrm{DM}$ ), high availability of potassium (181.0 $\left.\mathrm{mg} \mathrm{K} \mathrm{kg}^{-1} \mathrm{DM}\right)$, and very low availability of magnesium (16.0 mg Mg kg-1 DM). Humus content was at a level of $1.5 \%$, whereas the content of silty + clay $(<0.02 \mathrm{~mm})$ in the $0-30 \mathrm{~cm}$ layer was $22.0 \%$.

The experiment was set up in a randomised block design in three replicates, on plots with an area of $20 \mathrm{~m}^{2}$. In the experiment, the soybean cultivar 'Merlin' was grown. 
The experimental factor was the soybean fertilisation method: A1 - control treatment (without mineral fertilisation and EM); A2 - mineral NPK fertilisation; A3 - mineral NPK fertilisation and application of EM Naturalnie Aktywny + EM Ogród sprays before flowering $(\mathrm{BBCH}-$ Biologische Bundesanstalt, Bundessortenamt und Chemische Industrie - 55); A4 - spraying with EM Naturalnie Aktywny before sowing and with EM Naturalnie Aktywny + EM Ogród twice during plant growth (before flowering at $\mathrm{BBCH} 55$ and during pod development at $\mathrm{BBCH} 71$ ).

In treatment A4, the EM Naturalnie Aktywny spray was applied before sowing at a rate of $20 \mathrm{dm}^{3} \mathrm{ha}^{-1}$ per $300 \mathrm{dm}^{3} \mathrm{ha}^{-1}$ of water. During soybean growth, in treatments A3 and A4 the EM Naturalnie Aktywny + EM Ogród sprays were applied at a rate of $10 \mathrm{dm}^{3}+2 \mathrm{dm}^{3} \mathrm{ha}^{-1}$ per $300 \mathrm{dm}^{3} \mathrm{a}^{-1}$ of water (before flowering at $\mathrm{BBCH} 55$ and during pod development at $\mathrm{BBCH} 71$ ). EM Naturalnie Aktywny is a liquid organic fertiliser with soil microorganisms that improve soil fertility. Its composition contains lactic acid bacteria, photosynthetic bacteria, Azotobacter, yeasts, sugar cane molasses, and water. EM OGRÓD is an organic preparation for horticultural treatments which provides complete fertilisation and plant protection without chemicals. Its composition contains EM1, EM5, fermented herbal extracts, EM-X ceramic powder, and EM-X ceramic-activated water.

In treatments A2 and A3, all mineral fertilisers for the soybean crop were applied before sowing at the following rates: $\mathrm{N}-30 \mathrm{~kg} \mathrm{ha}^{-1} ; \mathrm{P}-40 \mathrm{~kg} \mathrm{ha}^{-1} ; \mathrm{K}-80 \mathrm{~kg} \mathrm{ha}^{-1}$. The fertiliser rates were determined based on the nutritional requirements of the crop and on soil nutrient availability. Tillage for soybean included skimming, harrowing twice, and autumn ploughing to a depth of $25 \mathrm{~cm}$. In the spring, the following operations were performed: harrowing, cultivating, harrowing, sowing, and harrowing after sowing.

Soybean was sown at the turn of April and May in a field after spring wheat at a seeding depth of $3 \mathrm{~cm}$, planned plant density of 100 plants per $1 \mathrm{~m}^{2}$, and row spacing of $35 \mathrm{~cm}$.

Before sowing, soybean seeds were inoculated with Bradyrhizobium japonicum bacteria (Nitragina) and the seed dressing Vitavax 200 FS (a.i. carboxin, thiuram) was applied at a rate of $0.4 \mathrm{dm}^{3} 100 \mathrm{~kg}^{-1}$ seed. Immediately after sowing, a mixture of the herbicides Afalon Dyspersyjny 450 SC (a.i. linuron) + Dual Gold 960 EC (a.i. S-metolachlor) was applied at an amount of $1 \mathrm{dm}^{3}+1.8 \mathrm{dm}^{3} \mathrm{ha}^{-1}$.

Measurements. Each year, the soybean crop was harvested in the second decade of September at full maturity (BBCH 89). Plant density after emergence and before harvest was estimated in two rows along a length of $2.5 \mathrm{~m}$. The yield components were determined based on a sample consisting of 30 randomly selected plants from each plot. The seed yield was weighed separately for each plot and the obtained results were expressed on a per hectare basis. 
To determine the number and weight of nodules on soybean roots, plants were dug out in three randomly selected places of each plot at the pod and seed development stage (BBCH 71/72). This determination was made based on 10 randomly selected plants from each plot.

The content of protein, oil and crude fibre in soybean seed were determined with reflectance spectroscopy (NIR-T) method using the Omega Analyzer Grain.

Statistical analysis. The results obtained during the period of 2014-2015 were statistically analysed using analysis of variance (ANOVA) and the significance of differences was evaluated by Tukey's test at $\alpha \leq 0.05$.

\section{Weather conditions}

The average air temperature in the soybean growing season (June-September) was $15.4^{\circ} \mathrm{C}$ in 2014 and $15.0^{\circ} \mathrm{C}$ in 2015 and it was higher by 1.0 and $0.6^{\circ} \mathrm{C}$, respectively, compared to the corresponding multi-year period (1974-2010). In both years of experiment, higher temperature than the multi-year average was recorded during seed filling and maturation (July-September). The average rainfall in the in the June-September period in both years exceeded the long-term average $(63.4 \mathrm{~mm})$ by $11.6 \mathrm{~mm}$ in 2014 and $2.2 \mathrm{~mm}$ in 2015, respectively. The highest rainfall in both growing seasons was recorded in May, just after sowing soybeans. Monthly rainfall was significantly higher than the average rainfall for May in the period of 1974-2010 (by $94.2 \mathrm{~mm}$ in 2014 and $112.2 \mathrm{~mm}$ in 2015). The lowest rainfall was recorded in August $2015(5.9 \mathrm{~mm})$ and in July $2014(35.9 \mathrm{~mm})$, lower than the multi-annual average for those months by $63.9 \mathrm{~mm}$ and $45.7 \mathrm{~mm}$.

\section{RESULTS AND DISCUSSION}

The experimental factor caused significant differences in soybean yield (Tab. 1). Application of mineral fertilisation supplemented by spraying with EM Naturalnie Aktywny before flowering (A3) had the most beneficial effect. Compared to the control treatment (A1), the seed yield was significantly higher, respectively by $81.0 \%$ in the plots with mineral fertilisation and EM (A3), by $79.7 \%$ in the plots with NPK fertilisation alone (A2), and by $23.5 \%$ in the treatment where the preparations containing effective microorganisms were applied (A4).

Many authors also indicate a positive effect of biological preparations on yields of other crops. Among others, a study by Sosnowski (2012) showed that combined application of a biological preparation called UGmax (lactic acid bacteria, photosynthetic bacteria, Azotobacter, Pseudomonas, yeasts, actinobacteria) with mineral fertilisation caused the highest increase in the yield of the following grasses: Dactylis glomerata L., Festuca pratensis Huds. and Lolium perenne L., compared to the control treatment. In the opinion of Trawczyński and Bogdanowicz (2007), higher crop productivity in treatments with soil amendment may be due to 
an increase in the soil humus content by even $17 \%$. The research on the use of effective microorganisms reveals that their effect on yield depends on the crop species. Hu and Qi (2013) showed that EM application in combination with compost resulted in a significant increase in straw and grain yield of winter wheat. Many authors indicate the positive influence of effective microorganisms on vegetable crop yields. By applying EM, Daly and Stewart (1999) obtained a 29\% higher onion yield as well as $31 \%$ higher bean and sweet corn yields, whereas Kleiber et al. (2014) found an increase in total and marketable tomato yield (respectively by 35.8 and $40 \%$ as well as by 44.6 and $35.9 \%$ ).

Table 1. Seed yield and some soybean traits and yield components depending on the fertilisation method (average for 2014-2015)

\begin{tabular}{|c|c|c|c|c|c|}
\hline \multirow{2}{*}{ Specimens } & \multicolumn{4}{|c|}{ Fertilisation } & \multirow{2}{*}{$\mathrm{LSD}_{0.05}$} \\
\hline & $\mathrm{A} 1 *$ & A2 & A3 & A4 & \\
\hline Seed yield $\left(\mathrm{t} \mathrm{ha}^{-1}\right)$ & 1.53 & 2.75 & 2.77 & 1.89 & 0.213 \\
\hline Plant density after emergence (plants $\mathrm{m}^{-2}$ ) & 64.3 & 66.0 & 70.6 & 63.4 & 2.23 \\
\hline Plant density before harvest (plants $\mathrm{m}^{-2}$ ) & 62.4 & 64.8 & 69.4 & 60.3 & 3.79 \\
\hline Plant height $(\mathrm{cm})$ & 43.6 & 51.6 & 53.5 & 47.2 & 5.27 \\
\hline First pod height (cm) & 7.4 & 6.9 & 6.4 & 7.3 & 0.90 \\
\hline Number of pods per plant (pcs.) & 12.0 & 17.0 & 18.0 & 13.2 & 0.93 \\
\hline Number of seeds per pod (pcs.) & 1.8 & 1.9 & 2.0 & 1.9 & n.s. $* *$ \\
\hline Number of seeds per plant (pcs.) & 21.3 & 32.5 & 34.8 & 25.4 & 1.35 \\
\hline Seed weight per plant (g) & 2.67 & 4.46 & 4.56 & 3.24 & 0.455 \\
\hline 1000 seed weight $(\mathrm{g})$ & 126.8 & 133.0 & 132.1 & 129.9 & n.s. \\
\hline
\end{tabular}

*A1 - control treatment (without fertilisation); A2 - mineral fertilisation; A3 - mineral fertilisation and EM application before flowering; A4 - pre-sowing application of EM + EM application twice during plant growth; $* *$ n.s. - no significant difference

Fertilisation method caused significant differences in most of the crop and yield components (Tab. 1). The highest plant density was found in the plots where NPK fertilisation and EM spraying were used (A3). In that treatment, the plant density after emergence and before harvest was higher by respectively 7.2 and 9.1 plants $\mathrm{m}^{-2}$ as well as by 6.3 and 7.0 plant $\mathrm{m}^{-2}$ relative to plots A4 and A1. The highest soybean plants were found in the treatment with the application of mineral fertilisation supplemented with EM spraying (A3), followed by the treatment where NPK fertilisation alone was applied (A2). Compared to the control treatment (A1), in plots $\mathrm{A} 3$ and $\mathrm{A} 2$ higher plants were observed, respectively by $9.9 \mathrm{~cm}$ and $8.0 \mathrm{~cm}$. An opposite relationship was found in the case of first pod height. In the control plot (A1), and in the treatment with EM application alone (A4), soybean plants set the first pods higher, which is a favourable characteristic when this crop is harvested. Compared to the control treatment (A1), all fertilisation methods caused a significant increase in the number of pods as well as in the number and weight of seeds 
per plant. The values of the above-mentioned traits were most favourable in the plots with mineral fertilisation and EM spraying (A3), followed by the treatment with NPK fertilisation alone (A2).

The experimental factor investigated in this study did not cause significant differences in 1000 seed weight (TSW) and number of seeds per pod (Tab.1). A slightly higher value of 1000 seed weight was obtained in all fertilisation treatments compared to the control treatment (A1). But, according to the study by Sulewska and Ptaszyńska (2005), EM1 application results in a significant increase in TSW and a slightly higher number of seeds per maize cob. Conversely, the experiment conducted by Javaid and Shah (2010) did not show effective microorganisms to positively influence the yield components, among others the number of grains per ear, and the grain yield of wheat.

The percentage protein and oil content in soybean seed differed depending on the experimental factor (Tab. 2). Compared to the control treatment (A1), all fertilisation treatments affected beneficially the seed protein content. The increase in the amount of this component compared to treatment A1 was the highest in the plots where effective microorganisms were applied (A3 and A4). The results for oil content in soybean seed were opposite. Seeds harvested from the control plot (treatment A1), where no mineral fertilisers or EM sprays were applied, showed the highest amount of this component. The percentage fibre content in soybean seed was not dependent on the fertilisation method. The increase in the protein content in soybean seed after EM spraying shown in this study may result from a larger amount of $\mathrm{N}$ accumulated in the plant. This is indicated e.g. by the research of Kleiber et al. (2014) who found an increase in $\mathrm{N}$ content in tomato plants in the case of EM application.

Table 2. Some quality characteristics of soybean seed depending on the fertilisation method (average for 2014-2015)

\begin{tabular}{|c|c|c|c|c|c|}
\hline \multirow{2}{*}{ Content of } & \multicolumn{4}{|c|}{ Fertilisation } & \multirow{2}{*}{$\mathrm{LSD}_{0.05}$} \\
\hline & A1* & A2 & A3 & A4 & \\
\hline Protein (\%) & 33.4 & 34.6 & 35.3 & 35.0 & 0.24 \\
\hline Oil (\%) & 19.5 & 19.0 & 18.4 & 19.0 & 0.15 \\
\hline Fiber $(\%)$ & 4.9 & 4.9 & 4.8 & 4.8 & n.s. $* *$ \\
\hline
\end{tabular}

Explanations as in Table 1

The nodule formation rate was promoted by the application of the EM sprays three times (Tab. 3). In that treatment (A4), the average number of nodules on the roots of a single plant was significantly higher, by $69.2,40.4$ and $34.7 \%$ compared to plots $\mathrm{A} 1, \mathrm{~A} 2$ and $\mathrm{A} 3$, whereas their weight was more than 2 times greater than that found in the control treatment (A1) (Tab. 3). 
Table 3. Average number and weight of nodules on the roots of a single soybean plant depending on the fertilisation method (average for 2014-2015)

\begin{tabular}{lccccc}
\hline \multirow{2}{*}{\multicolumn{1}{c}{ Specimens }} & \multicolumn{4}{c}{ Fertilisation } & \multirow{2}{*}{ LSD $_{0.05}$} \\
\cline { 2 - 5 } & $\mathrm{A} 1 *$ & $\mathrm{~A} 2$ & $\mathrm{~A} 3$ & $\mathrm{~A} 4$ & \\
\hline Number of root nodules (pcs.) & 3.9 & 4.7 & 4.9 & 6.6 & 1.24 \\
Weight of root nodules (g) & 0.25 & 0.43 & 0.45 & 0.51 & 0.14 \\
\hline
\end{tabular}

Explanations as in Table 1

\section{CONCLUSIONS}

1 Compared to the control treatment, all fertilisation treatments resulted in a significant increase in soybean seed yield.

2. Application of mineral fertilisation supplemented by spraying with effective microorganisms (A3) proved to be the most beneficial for soybean yield, followed by the treatment with NPK fertilisation alone (A2). In the above-mentioned treatments (A3 and A2), plant density after emergence and before harvest, plant height, number of pods as well as number and weight of seeds per plant were also found to be the highest.

3. All fertilisation treatments had a beneficial effect on protein content in soybean seed compared to the control treatment (A1), in particular those in which effective microorganisms were applied (A3 and A4).

4. The highest oil content in soybean seed was found in the control treatment where no mineral fertilisation or EM spraying were applied (A1).

5. The rate of nodule formation, as expressed by the number and weight of nodules on soybean roots, was supported to the greatest extent by the application of the EM sprays three times (A4).

6. Preparations containing effective microorganisms can be used in sowing soybean, especially in combination with mineral fertilisation. They have a favourable impact on soybean yield and protein content in the seeds of this plant.

\section{REFERENCES}

Cederroth Ch.R., Nef S., 2009. Soy, phytoestrogens and metabolism. Mol. Cell. Endocrinol., 304, 3-42, doi:10.1016/j.mce.2009.02.027

Condor Golec A.F., Gonzales Perez P., Lokare CH., 2007. Effective Microorganisms. Myth or reality? Rev. Peru. Biol., 14(2), 31-319.

Daly M.J., Stewart D.P.C., 1999. Influence of "effective microorganisms" (EM) on vegetable production and carbon mineralization - A preliminary investigation. J. Sustain. Agr., 14(2-3), 15-25, doi:10.1300/J064v14n02_04

Elkoca E., Kantara F., Sahinb F., 2008. Influence of nitrogen fixing and phosphorus solubilizing bacteria on the nodulation, plant growth, and yield of Chickpea. J. Plant Nutrition, 31(1), 157-171 https://doi.org/10.1080/01904160701742097 
Gawęda D., Cierpiała R., Bujak K., Wesołowski M., 2014. Soybean yield under different tillage systems. Acta Sci. Pol., Hortorum Cultus, 13(1), 43-54.

Harasim E., Gawęda D., Wesołowski M., Kwiatkowski C., Gocół M. 2016. Cover cropping influences physicochemical soil properties under direct drilling of soybean. Acta Agr. Scan. Sec. B-Soil Plant Science, 66(1), 85-94.

$\mathrm{Hu}$ Ch., Qi Y., 2013. Long-term effective microorganisms application promotes growth and increase yields and nutrition of wheat in China. Europ. J. Agron., 46, 63-67, doi:10.1016/j.eja.2012.12.003

Javaid A., Bajwa R., Anjum T., 2008. Effect of heat-sterilization and EM (effective microorganisms) application on wheat (Triticum aestivum L.) grown in organic-amended sandy loam soil. Cereal Res Commun., 36(3), 489-499, doi:10.1556/CRC.36.2008.3.13

Javaid A., Shah M.B.M., 2010. Growth and yield response of wheat to EM (effective microorganisms) and parthenium green manure. Afr. J. Biotechnol., 9(23), 3373-3381.

Khaliq A., Kaleem Abbasi M., Hussain T., 2006. Effects of integrated use of organic and inorganic nutrient sources with effective microorganisms (EM) on seed cotton yield in Pakistan. Bioresource Technol., 97, 967-972, doi:10.1016/j.biortech.2005.05.002

Kleiber T., Starzyk J., Górski R., Sobieralski K., Siwulski M., Rempulska A., Sobiak A., 2014. The studies on applying of effective microorganisms (EM) and CRF on nutrient contents in leaves and yielding of tomato. Acta Sci. Pol., Hortorum Cultus, 13(1), 79-90.

Łabuda H., Buczkowska H., 2014. Biologically active substances in the broad bean green seeds after storage in the pods. Acta Sci. Pol., Hortorum Cultus, 13(4), 83-93.

Mayer J., Scheid S., Widmer F., Fließbach A., Oberholzer H., 2010. How effective are "Effective microorganisms (EM)"? Results from a field study in temperature climate. Appl. Soil Ecol., 46(2), 230-239, doi:10.1016/j.apsoil.2010.08.007

Muthaura Ch., Musyimi D.M., Ogur J.A., Okello S.V., 2010. Effective microorganisms and their influence on growth and yield of pigweed (Amaranthus dubians). ARPN J. Agric. Biol. Sci., 5(1), 17-21.

Sosnowski J., 2012. Reaction of Dactylis glomerata L., Festuca pratensis Huds. and Lolium perenne L. to microbiological fertilizer and mineral fertilization. Acta Sci. Pol., Agricultura, 11(1), 91-98.

Sulewska H., Ptaszyńska G., 2005. Reakcja kukurydzy uprawianej na ziarno na stosowanie preparatów mikrobiologicznych. Pam. Puł., 140, 271-285.

Trawczyński C., Bogdanowicz P., 2007. Wykorzystanie użyźniacza glebowego w aspekcie ekologicznej uprawy ziemniaka. J. Res. Appl. Agr. Eng., 52(4), 94-97.

Woźniak A., 2012. Weed infestation of pea (Pisum sativum L.) crop under the conditions of plough and ploughless tillage. Acta Sci. Pol., Hortorum Cultus, 11(2), 253-262.

Woźniak A., 2013. The yielding of pea (Pisum sativum L.) under different tillage conditions. Acta Sci. Pol., Hortorum Cultus, 12(2), 133-141.

Zeller F.J., 1999. Die Sojabohne (Glycine $\max$ (L.) Merr.): Nutzung, Genetik, Biotechnologie. Die Bodenkultur, 50(3), 191-2002. 


\title{
PLONOWANIE, JAKOŚĆ NASION ORAZ BRODAWKOWANIE SOI W WARUNKACH STOSOWANIA EFEKTYWNYCH MIKROORGANIZMÓW
}

(EM)

\author{
Dorota Gawęda, Matgorzata Haliniarz, Andrzej Woźniak, Elżbieta Harasim
}

Katedra Herbologii i Technik Uprawy Roślin, Uniwersytet Przyrodniczy w Lublinie ul. Akademicka 13, 20-950 Lublin

e-mail: elzbieta.harasim@up.lublin.pl

Streszczenie. Soja jest rośliną strączkową o szczególnie wysokich walorach użytkowych, cenioną przede wszystkim za wysoką zawartość białka i tłuszczu w nasionach. Ze względu na celowość poszukiwania optymalnych rozwiązań w agrotechnice tej cennej rośliny strączkowej podjęto badania, których zamierzeniem było określenie wpływu różnych sposobów nawożenia $\mathrm{z}$ wykorzystaniem preparatów EM (zawierających efektywne mikroorganizmy) na plonowanie, zawartość wybranych składników jakościowych w nasionach i brodawkowanie soi. Eksperyment założono metodą losowanych bloków w trzech powtórzeniach, na poletkach o powierzchni $20 \mathrm{~m}^{2}$. Uprawiano soję odmiany Merlin. Wykazano, iż najkorzystniejsze dla plonowania soi okazało się zastosowanie nawożenia mineralnego uzupełnionego opryskiem preparatem $z$ efektywnymi mikroorganizmami (EM), a następnie wyłącznego nawożenia NPK. Wszystkie warianty nawożenia oddziaływały korzystnie na zawartość białka w nasionach soi w porównaniu do obiektu kontrolnego. Odwrotną zależność stwierdzono w przypadku procentowej zawartości tłuszczu. Największą liczbę i masę brodawek na korzeniach soi odnotowano w warunkach trzykrotnego oprysku efektywnymi mikroorganizmami.

Słow a kluczow e: Glycine max L., EM, plon nasion, skład chemiczny nasion, liczba i masa brodawek, elementy struktury plonu 